\title{
日本鉱業会における超微料酸化物の製造に 関する研究委員会の活動状況*
}

八 嶋 三 郎**

Saburō YASHIMA

\section{1.はじめに}

鉱物処理工学関係で微粒子の取り扱いが問題となっ た発端は 1980 年 2 月 24 28日に米国の Nevada 州 Las Vegasで開催されたThe International Symposium on Fine Particles Processingである。いま Prof.P.Somasundaran (Columbia University Henry Krumb School of Mines)の編集になるこの 会議の proceedingsをひもとくと，今から 4 年前, 世 界の研究者らはこの問題について何を考えており，そ れをどう解決しようとしていたのかを知ることができ る。思うにての問題は，今や世界的に有用鉱物を含む 資源が貧鉱と化しつつあり，乙れを処理して目的鉱物 を分離回収するためには，いっそう細かく粉砕して単 体分離を進めたうえで分離しなりればならないことは 必定で, 必然的に微粒子の処理が将来之も可成り長い 期間にわたつて問題となるはずで，今のうちにての問 題にチャレンジしておかなりれば……，という考えが 念頭にあってのととと考えられる。残念ながら紙幅の 都合でその全部をとこに転載することはできないが, 一部を以下に揭げよう。11の項目につき全部で 91 の研 究があった。各項目の括弧內の数字はそれぞれの論文 数であり, 代表的なすの数編ずつにつき題目之著者名 を掲げた。

\section{Las Vegasで開催された微粒子の処理に関す る国際シンポジウム}

\section{Production of Fines and Ultrafines (9)}

1. Generation and Measurement of Fine-Crystal Distributions

\section{A.D.Randolph}

昭和 59 年 8 月 2 日受付

* 粉体工学会第20回夏期シンポシウムにて発表 (1984. 7. 函南)

** 東北大学選鉱彆鍊研究所 (平 980 仙台市片平二丁目 1 番 1 号) TEL $0222-(27)-6200$ (内) 2425
2. Preparation and Properties of Fine Lead Zirconate Titanate Powders

$$
\text { Ramjilal, P.Ramakrishnan }
$$

3. Freeze-Drying-A Method for the Preparation of Fine Sinterable Powders and Low Temperature Solid State Reaction

$$
\text { M.Paulus }
$$

4. On the Feasibility of Using a Radioactive Tracer Method and a Size-Discretized Mass Balance Model for the Measurement of Growth rates in MSMPR Crystallizers

$$
\text { R.P.Gardner, K.Verghese, R.W.Rousseau }
$$

2. Classification, Mixing, and Flow (8)

10. A Review of Two Fine Particle Processing Unit Operations-Classification and Mixing

$$
\text { P. Luckie, R. Hogg , R. Schaller }
$$

11. A Study of the-Effect of Improved Pneumatic Classification on Micropowder Production

$$
\text { R.T.Hukki, T.Airaksinen }
$$

12. Performance Characteristics of the University of Tronto Infrasizer MK III

$$
\text { B. Etkin, A.A.Haasz }
$$

13. Air-Float Conveying of Particulate Bulk Solids

$$
\text { C.R.Woodcock, J.S.Mason }
$$

3. Characterization of Particles and Particle Systems (14)

18. Particle Size Analysis-A Review

$$
\text { G.C.Sresty, R.Venkateswar }
$$

19. A New Simple and Sensitive On-Line Particle Size Analyzer for Fine Powders Suspended in Gases

\section{L.Svarovsky, R.S.Hadi}

20. Particle Size Distribution Measurements in the Submicron Radius Range by the Method 
of Spectral 'Transparency

$$
\text { L.P. Bayvel }
$$

21. Characterization of Oil-in-Water Emulsions : An Evaluation of the Coulter Counter Technique

$$
\text { H. A. Hamza, N. E. Andersen }
$$

\section{Surface Chemical Aspects (3)}

32. Potential, Charge and Ion Mobility Studies on Oxide Surfaces

\section{M.P.Sidorova, D. A. Fridrikhsberg}

33. An Improved Method of Determining the Zeta-Potential of Mineral Particles by Micro-Electrophoresis

$$
\text { S.Mori, H.Okamoto, T. Hara, K. Aso }
$$

34. Effects of Pretreatments on the Surface Characteristics of a Natural Magnetite

L.O. Kolarik, D.R.Dixon, P.A. Freeman, D. N. Furlong, T.W. Healy

\section{Fine Particles Flotation (13)}

35. Fine Particle Flotation

$$
\text { D.W. Fuerstenau }
$$

36. Influence of Some Factors on Fine Particle Flotation

$$
\text { O.S. Bogdanov, M.F. Emelyanov }
$$

37. Formation and Disruption of Particle-Bubble Aggregates in Flotation

$$
\text { A. Jowett }
$$

38. Differences Between Particle Flotation and Floc Flotation

$$
\text { U. Neis, K.P. Kief haber }
$$

\section{Flocculation, Dispersion, and Selective} Flocculation (11)

48. Principles of Flocculation, Dispersion, and Selective Flocculation

\section{P.Somasundaran}

49. Processing of Indian Coal-Fines T.C.Rao, P. Bandopadhyay

50. Flocculation Problems in the Coal Industry

$$
R \text {. Hogg }
$$

51. Flocculation and Dispersion Phenomena Af fecting Phosphate Slime Dewatering G.Y.Onoda, Jr., D.M. Deason, R. M. Chhatre

7. High Intensity Magnetics and Electrostatics $(10)$

59. Advances in Application of Magnetic and
Electric Techniques for Separation of Fine Particles

$$
\text { Y.Zimmels, I.J.Lin, I.Yaniv }
$$

60. Recent Advances in High Gradient Magnetic Separation

$$
\text { J. A.Oberteuffer, I. Wechsler }
$$

61. A Loading Equation for High Gradient Magnetic Separators and Application in Identifying the Fine Size Limit of Recovery

$$
\text { J.E. Nesset, J.A. Finch }
$$

62. Processing Finely Ground Oxidized Taconite by Wet High-Intensity Magnetic Separation

$$
\text { D.M.Hopstock, A.F.Colombo }
$$

\section{Gravity and Hidrometallurgy (3)}

69. Slime Recovery by Gravity ConcentrationA Viable Alternative?

$$
\text { R.O. Burt }
$$

70. Gravitational Beneficiation of Ultrafine Grains of Zinc-Lead Ores from Olkusz Region

$$
\text { W. Blaschke, E. Malysa }
$$

71. Hidrometallurgical Processing of Fine Mineral Particles

$$
\text { G.W.Warren, M.E.Wadsworth }
$$

\section{Agglomeration (6)}

72. Agglomeration-The State of the Art

$$
\text { C. A. Holley }
$$

73. Principles and Applications of Size Enlargement in Liquid Systems

$$
\text { C.E.Capes }
$$

\section{Solid/Liquid Separation (8)}

78. A Revised Approach to the Theory of Cake Filtration

$$
\text { F.M.Tiller, J.R.Crump, F.Ville }
$$

79. Effects of Particle Properties on Filtration of Aqueous Suspensions

$$
\text { M. E.Tadros, I. Mayes }
$$

11. Waste Treatment (6)

86. Resources Potential of Mineral and Metallur. gycal Wastes

$$
\text { H.S. Hanna, C. Rampacek }
$$

87. Solid Waste Disposal in the Mining Industry

$$
\text { R.D.Hill, J.L. Auerbach }
$$




\section{3. 微粒子の鉱物処理工学研究委員会の活動状況}

このような状勢から，日本鉱栄会內に微粒子の鉱物 処理工学研究委員会が設置され, 昭和 56 年度と昭和 57 年度の 2 ケ年にわたり, 日本鉱燢振興会から研究費の で援助をいただいて微粒子の鉱物処理工学に関する研 究を実施し，その成果をそれぞれ昭和57年度之昭和 58 年度の全国地下資源関係学協会合同秋季大会（昭和57 年10月 15 17日, 北九州市, 昭和 58 年10月 $6 \sim 8$ 日, 仙台市）において報告した。その際各研究委員が報告 した研究題目はつぎのようである。

\section{昭和 57年の秋季大会}

1. 高速衝撃による微粉砕

東大 井上外志雄・岡屋克則

2. 石油ピッチの微粉砕

東北大 八嶋三郎・山本泰二・堀田浩充・荒 井豊

3. 担体浮選の適用性の検討

岩手大 長谷部 茂・中沢 広

4. 鉱物の微粒化に伴う物性およひ浮選特性の変化 京大 若松貴英・中広吉孝

5. 微細鉄鉱石の逆浮選（その 1$)$ ーヘマタイトとディッカイトの分離一 東北大 下飯坂潤三・東亜興発 福岡 信 東北大 吉川逸治

6. 钽細鉄鉱石の逆浮選（その 2 ) 一ヘマタイトと石英の分離一

東北大 日井進之助・武田 進

7. 堂屋敷選鉱工場におりる微粒子の浮選挙動 同和鉱業花岡 金谷浩一郎・恩田達也・桜庭 正則

8. H GM S による微粒子鉱物の処理

日鉄鉱業 堀田祐邦 - 山崎久雄 - 俣川恭輔 柏村康輔・中田三郎

9. 明延鉱山における粒度別錫選鉱について 明延釷業明延 松山弘志・閒脇秀行

\section{昭和 58年の秋季大会}

1. 粉砕助剂による乾式微粉砕

東北大 八嶋三郎 富士石油・荒井 豊

2. 微粒子の分級技術について

一湿式分級の可能性一

東大 岡屋克則・井上外志雄

3. 堂屋敷選鉱工場におけるミルフィードの粉研特
性

同和鉱業花岡 金谷浩一郎・恩田達也・桜庭 正則・川口 純

4. 鉱物の微粒化に伴う物性の変化之浮遊性 京大 中広吉孝・若松貴英

5. Removal of Pyrite from Dickite by High Gradient Magnetic Separation

Tohoku Univ. Junzo Shimoiizaka and Young Sam Kim

6. 担体浮選の適用性の検討 岩手大 長谷部 茂・佐藤敏人・中沢 広

7. モノー，ジーおよびトリアミンによる微粒鉄鉱 石の脱珪浮選

東北大 日井進之助・武田 進

なおての研究委員会には大学側委員のほかに住友金 属鉱山(株), 同和釷業(株)，日鉄鉱業(株)，日本鉱業 (株), 三井金属鉱業(株), 三菱金属(株)の各社加ら委 員が参画した。

\section{4. 超微粒酸化物の製造に関する研究委員会の活動 状況}

“近年におりる各種金属酸化物の電子材料，セラミッ クス材料，機能材料への用途の拡大は極めて著しいも のがある。酸化物の種類の広がりももちろんではある が，個々の酸化物についてもその使用目的によって， 種々の粒度あるいは形状のあのが要求される。たとえ ばオーディオおよびビデオ用テープ材料としての酸化 鉄についてみれば, 材質的にはどれあ $r-\mathrm{Fe}_{2} \mathrm{O}_{3}$ であ るが，ゲーサイト経由で製造したものと，レピドクロ サイト経由で製造したものとでは，製品の磁気特性や 形状に若干の差異がみられ，r-F- $\mathrm{Fe}_{2} \mathrm{O}_{3}$ 上にコバルト 酸化物をエピタキシャル生長させた場合の特性にあ製 造経路の差異があらわれる。また $r-\mathrm{Fe}_{2} \mathrm{O}_{3}$ あ従来は $20 \mathrm{~m}^{2} / \mathrm{g}$ 程度の微粒子でよいとされて来たあのが, 最 近では目的によっては $40 \mathrm{~m}^{2} / \mathrm{g}$ 以上の比表面積をすつ あのが要求されるようになり，そのうえ形状について あ針状結晶のものだけでは不充分とされ，紡鍾状粒子 の製造に対する要求む增大している。

電子材料，七ラミックス材料やその他の機能材料に 対する要求む，それらの材料を必要とする分野におけ る技術の開発と共に大きく変化している。現段階では 電子材料として粒度のそろった平均粒径 $0.5 \mu \mathrm{m}$ 程度の 粒子が要求されることが多く，七ラミックス材料とし てはさらに微粒の平均粒径 $0.05 \mu \mathrm{m}$ くらいのあのが要 
求されるととが多いが，焼結時におりる反応性などの 面から，さらに微粒子が要求されることもある。また 合織に混入する觎電性白色微柆子などは基本となる白 色微柆子そのすのが超微粒子であるととが必要である。 てのように見て来ると, 脱水, 婄姘過程における颣集, 始結を防止して超微柆子を製造するための基礎となる 技術を確立しておくことは極めて重要である。このよ うな钼点から，一応 3 年間の計画で, 日本鉱業振興会 から研究费のご支援を迎ぎ，標記の研究委員会が昭和 58年度から発足した。

本研究委員会では化学的手法ならびに機械的手法に よろ超改柆酸化物の製造に重点を圈いて研究を進める とととし，以下のように研究課題を分担した。

1. 形状ならびに柆子径のそろった超微粒酸化鉄の 㱔造阙する研究

東北大 佐々木弘委員

2. 湿式法によるスピネル型袮合酸化物微粒子の生 成と水相分散に関する研究

東北大 下飯坂调三委員

3. 摩砕による超微粉体の製造に関する研究 東北大 八郎委員

4. 湿式ボールミル粉碎による超微粉体の彆造に関 する研究

山形大 神田良照委員

5. 超高速街篻による超微粉体の生成法の研究 同志社大 奥田 恥委員

6. 超微柆酸化物の製造に関する文献調查 京大 真嶋 宏委員

てのようにして各委員とあに研究を開始しているが, てれまで数回にわたり研究遂行に資するために各委員 のそれぞれの分野における研究成果の報告会を開き討 維を行って来た。それを紹介するとつぎのようである。

1. 破汇よる超微粉体の製造に関する基礎的研究 昭和58年 8 月 23 日(東京) 東北大 八的三郎 委員

2. 败粉碎と粉碎エネルギー 昭和58年 8 月 23 日(東京) 山形大 神田良炤 委員
3. 懸濁液の分散

昭和58年 12 月 20 日（東京） 東北大 下飯坂閏 三委員

4. 単分散超微粒酸化物の生成とその性質 昭和58年12月20日（東京）東北大 佐々木 弘委員

5. ジェットミルによる超微粉体の生成 昭和 59 年 3 月 28 日(東京) 同志社大 奥田 聡委員

6. 磁性流体

昭和59年 3 月 28 日（東京） 東北大 下飯坂潤 三委員

7. 金属微粒子の合成と分散化処理について 昭和 59 年 7 月 4 日(東京) 東北大 中塚勝人 委員

8. プラズマ性ガスによる超微粒化について 昭和59年 7 月 4 日(東京) 金材研 宇田雅広

9. 微粉体のメカノケミカル活性化 昭和 59 年 7 月 4 日（東京） 慶応大 仙名 保

なお， 7 の中塚勝人委員は昭和 59 年度から下飯坂瀾 三委員と交替して新しく委員となり，また 8 の宇田雅 広氏と 9 の仙名保氏は，特に出席していただいて講演 をお願いした。との研究委員会の委員は公募により委 啒されており, 上記の大学側委員のほかに, 坂本宏委 員一公害資源研究所資源第 3 部一が参画しており，ま た会社側からは住友金属鉱山(株)，東邦亜鉛(株), 同 和鉱業(株), 日本鉱業(株), 古河鉱業(株), 三井金属 鉱業(株), 小野田セメント(株), チタン工業(株)から それぞれ委員が参画している。

\section{5. むすび}

以上日本鉱業会における微柆子関係の研究委員会の 活動状況に重点をおいて，鉱物処理工学における微粒 子の取り扱いに関する研究の流れを概観した。今回粉 体工学会において開催された第20回夏期シンポジゥム 「サブミクロン柆子の制御と応用」において, 標記の 委員会の現況を報告する機会を与えられたてとを深謝 申し上げると共に本シンポジウムと，粉体工学会のど 発展を祈念します。 